\title{
MORPHOLOGICAL AND CHEMICAL CONNECTIVE TISSUE CHANGES IN FIBROSITIC MUSCLES*
}

\author{
BY
}

\author{
P. BRENDSTRUP, K. JESPERSEN, AND G. ASBOE-HANSEN \\ From the Military Hospital, Department of Physical Medicine ${ }^{\dagger}$, and the \\ Connective Tissue Research Laboratory $\ddagger$, University Institute of Medical Anatomy, Copenhagen
}

The changes occurring in the muscles of patients suffering from muscular pain owing to fibrositis have been the subject of much discussion. Scientific theories have been chiefly based on objective findings, especially the results of microscopical examinations. Stockman (1920) found hyperplasia of the connective tissue with sero-fibrinous exudation. Microscopy of skeletal muscles with fibrositis supposed to have existed for several years has revealed degenerative changes in the muscle cells and an increase in the number of nuclei (Glogowski and Wallraff, 1951). Other workers (e.g. Schade, 1921 ; Lange, 1925) have found only normal muscle in biopsy specimens of fibrositic tissue.

It is more or less agreed that with some practice it is possible to palpate some abnormality in certain patients but a satisfactory histopathological explanation of the disorder has not yet been found. In the following study one of us (K.J.) has made the clinical examination, especially the palpation, another (P.B.) has carried out chemical analyses by means of an improved technique, and the third author (G.A.-H.) has made microscopic examinations of the same biopsy specimens. Our object was to discover whether it is possible to demonstrate in fibrositic areas a lesion of the intercellular and interfibrillar connective tissue.

\section{Material and Methods}

Biopsy specimens were obtained from patients operated on for herniation of the nucleus pulposusई. In such patients fibrositis in the lumbar muscles is very common. It may either arise secondarily to the prolapse or develop concurrently with it in consequence of the same overstrain. The patients were prevented from lying on one

* This work was aided by grants from the National Danish Association against Rheumatic Diseases, and Eli Lilly and Co. Indianapolis, Indiana, U.S A.

+ Head: K. Jespersen, M.D.

\$ Head: G. Asboe-Hansen, M.D. side for long periods. Before the operation palpation $\vec{\sigma}$ of the muscles was performed with the patient under general anaesthesia, the muscles being relaxed by an injection of curare. When pronounced fibrositic areas $\infty$

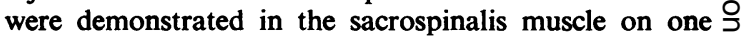
side and little or no abnormality on the other, biopsy specimens (weighing 1.5 to $2 \mathrm{~g}$.) were removed from symmetrical areas on both sides through the surgical incision. A diagnosis of fibrositis could thus be made on an objective basis, without misleading indications of ${ }_{\mathbb{Q}}$ tenderness by the patient. The complete relaxation of the muscles ensured that the phenomena detected bf $\vec{\theta}$ palpation were changes in consistency and not tensio due to muscular contractions.

Twelve sets of biopsy specimens were submitted to microscopical examination. They were fixed in a 4 per cent. aqueous lead subacetate solution, and the sections $\overline{0}$ were stained with a 0.5 per cent. aqueous toluidine blue solution in order to determine the localization and $\mathbb{\perp}$ content of acid mucopolysaccharides. The water, $\vec{F}$ hexosamine, potassium, and chloride content was determined chemically in order to obtain information regarding the oedema and the mucopolysaccharide content of the extracellular space. The methods employed have been described by Brendstrup (1957).

\section{Results}

Microscopic Examination.-In nine of the twelve fibrositic specimens, a metachromatic substance was found in the interfibrillar connective tissue, indicating $ᄋ$ acid mucopolysaccharides. In seven cases, widening of the interstices were noticed, indicating oedema. In six specimens, a relatively increased number of nuclei was found in the muscle; in six, an increased $\sigma$ number of mast cells was seen in the connective $N$ tissue; in four, a slight accumulation of lympho- N cytes was noted; in one, a few polymorphonuclear $O$ leucocytes were seen. Two specimens were absolutely normal.

$\S$ Thanks are due to Professor E. Busch, M.D., Department of meurosurgery, University of Copenhagen, for placing the tissue Naterial at our disposal. 
Of the twelve control specimens from normal muscles, none presented pronounced changes. In three of the control specimens some metachromatic staining of the intercellular connective tissue was observed, in three an increased number of nuclei, and in one a few perivascular lymphocytes. Eight were perfectly normal.

Chemical Analysis.-In the fibrositic muscle specimens, the dry substance constituted on an average 25.9 per cent., and in the control specimens 28 per cent. There is between 90 and 95 per cent. probability that this increase in the fluid content of fibrositic muscles is real.

The potassium concentration was on an average 5 per cent. lower in the fibrositic muscle than in the control. There is a 80 to 90 per cent. probability that the observed reduction of the potassium concentration is real.

Both the chloride and the hexosamine concentrations were on an average 50 per cent. higher in the fibrositic muscles than in the control specimens. There is more than 95.5 per cent. probability that this represents a real increase in the chloride and hexosamine concentrations in fibrositic muscle.

The results in eleven specimens are shown in the Table.

\section{Discussion}

A striking difference was seen between the microscopic pictures of the fibrositic specimens and those of the controls.
This indicates the existence of a morphological basis for the palpatory finding in the fibrositic tissue, namely an interstitial mucinous oedema containing acid mucopolysaccharides in the connective tissue of the muscle, as well as an accumulation of mast cells, which are generally considered to be the origin of mucopolysaccharide substances.

The chemical analyses bore out the microscopic observations. Hexosamine is an indispensable component of acid mucopolysaccharides, and the hexosamine concentration in connective tissue is an indication of its content of acid mucopolysaccharide to which hyaluronic acid belongs. Hyaluronic acid has a strong water-binding capacity (Ropes, Robertson, Rossmeisl, Peabody, and Bauer, 1947). In the experiments here reported, the fluid content was found to be on an average 8 per cent. higher in the fibrositic muscles than in the controls.

Determinations of the chloride and potassium content provide some information on the relative sizes of the intra- and extracellular spaces and on the possible changes in the distribution of the fluid content when the muscle becomes fibrositic. The muscle cells contain indiffusible anions in a high concentration. Diffusible chlorine ions are normally found chiefly extracellularly, their concentration being similar to that of blood plasma. Potassium, on the other hand, is found mainly intracellularly.

The extracellular space constitutes about 10 per cent. of the normal muscle volume (Boyle, Conway,

TABLE

DRY MATTER, POTASSIUM, CHLORIDE, AND HEXOSAMINE IN FIBROSITIC MUSCLES

\begin{tabular}{|c|c|c|c|c|c|c|c|c|c|}
\hline \multirow{2}{*}{\multicolumn{2}{|c|}{$\begin{array}{l}\text { Case } \\
\text { No. }\end{array}$}} & \multicolumn{2}{|c|}{$\begin{array}{c}\text { Dry Matter } \\
\text { (per cent.) }\end{array}$} & \multicolumn{2}{|c|}{$\begin{array}{c}\text { Potassium } \\
\text { (mEq. wet weight) }\end{array}$} & \multicolumn{2}{|c|}{$\begin{array}{c}\text { Chloride } \\
\text { (mEq. wet weight) }\end{array}$} & \multicolumn{2}{|c|}{$\begin{array}{c}\text { Hexosamine } \\
\text { (mg. per cent. wet weight) }\end{array}$} \\
\hline & & Fibrositic & Normal & Fibrositic & Normal & Fibrositic & Normal & Fibrositic & Normal \\
\hline 1 &.. & $23 \cdot 7$ & $24 \cdot 6$ & $20 \cdot 7$ & $22 \cdot 1$ & $9 \cdot 2$ & $7 \cdot 0$ & $23 \cdot 7$ & $15 \cdot 5$ \\
\hline 2 &. & 30.9 & $32 \cdot 4$ & $31 \cdot 9$ & $36 \cdot 8$ & $9 \cdot 6$ & $8 \cdot 2$ & $19 \cdot 5$ & $11 \cdot 0$ \\
\hline 3 & .. & - & - & $30 \cdot 0$ & $24 \cdot 8$ & 9.9 & $7 \cdot 6$ & $19 \cdot 2$ & $11 \cdot 5$ \\
\hline 4 & $\cdots$ & $26 \cdot 1$ & $21 \cdot 6$ & $21 \cdot 6$ & $17 \cdot 6$ & $10 \cdot 8$ & $7 \cdot 0$ & - & - \\
\hline 5 &. & $24 \cdot 0$ & $25 \cdot 6$ & $26 \cdot 4$ & $30 \cdot 0$ & - & - & $11 \cdot 4$ & $8 \cdot 0$ \\
\hline 6 & $\cdot$ & $18 \cdot 2$ & $24 \cdot 0$ & $15 \cdot 1$ & $20 \cdot 1$ & $17 \cdot 0$ & $9 \cdot 8$ & $17 \cdot 0$ & $8 \cdot 3$ \\
\hline 7 & $\cdots$ & 28 & 25 & $22 \cdot 6$ & $22 \cdot 8$ & $10 \cdot 6$ & $6 \cdot 2$ & $16 \cdot 2$ & $11 \cdot 7$ \\
\hline 8 & $\cdots$ & 31 & $29 \cdot 5$ & $26 \cdot 0$ & $22 \cdot 7$ & $10 \cdot 1$ & $7 \cdot 5$ & $14 \cdot 3$ & $10 \cdot 2$ \\
\hline 9 & $\cdots$ & 20 & 25 & $14 \cdot 6$ & $23 \cdot 9$ & - & - & $17 \cdot 5$ & $11 \cdot 7$ \\
\hline 10 & . & 29 & 40 & $21 \cdot 5$ & $27 \cdot 2$ & $10 \cdot 8$ & $7 \cdot 4$ & $22 \cdot 4$ & $17 \cdot 1$ \\
\hline 11 & $\cdots$ & 28 & 32 & $24 \cdot 7$ & $22 \cdot 5$ & $9 \cdot 0$ & $4 \cdot 0$ & $16 \cdot 0$ & $12 \cdot 9$ \\
\hline Mean & 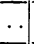 & $25 \cdot 9$ & $28 \cdot 0$ & $23 \cdot 2$ & $24 \cdot 6$ & $10 \cdot 8$ & $7 \cdot 2$ & $17 \cdot 7$ & $11 \cdot 8$ \\
\hline$t$ & . & \multicolumn{2}{|c|}{$1 \cdot 47$} & \multicolumn{2}{|c|}{0.93} & \multicolumn{2}{|c|}{$3 \cdot 23$} & \multicolumn{2}{|c|}{8.49} \\
\hline
\end{tabular}

$t$ determinations based on a comparison between analyses on the fibrositic and control sides of the same patient. 
Kane, and O'Reilly, 1941). In the fibrositic specimens subjected to chemical analysis, it had increased to about 15 per cent., as the chloride concentration was on an average 50 per cent. higher in the fibrositic specimens than in the controls. On the basis of the potassium determinations, the intracellular space had decreased from the normal 90 per cent. to an average of 85 per cent. in the fibrositic muscles. However, this reduction in the size of the intracellular space was just relative. In the fibrositic muscles, the fluid content was found to be increased by a scant 8 per cent., thus fully compensating for the relative decrease in size of the intracellular space. The analyses revealed, in other words, a considerable increase of the volume of the extracellular space in the fibrositic tissue, and possibly also a minor increase of that of the intracellular space.

The reason for the increase of the mucopolysaccharide concentration in the fibrositic muscles is open to speculation. Boas and Foley (1954) found that mechanical or chemical irritation of connective tissue causes an increase in the hexosamine concentration. An increase like this may be secondary to an oedema (Wegelius and Asboe-Hansen, 1956), which manifests itself in the firmer consistency and to some extent also in the increased volume of the affected muscle. The painfulness of the fibrositic muscles may well be explained by distension alone.

Summary
Histological and chemical analyses of biopsy
specimens of fibrositic muscles in patients suffering
from herniation of nucleus pulposus revealed an
increased concentration of acidmucopolysaccharides,

increased water content localized in the extra- $\frac{\bar{D}}{\mathrm{D}}$ cellular space, and increased chloride and hexo- 3 samine content. A slight accumulation of mast음 cells were found in histological sections.

\section{REFERENCES}

Boas, N. F., and Foley, J. B. (1954) Proc. Soc. exp. Biol. (N.Y.), 86, 690 .

Boyle, P. J., Conway, E. J., Kane, F., and O'Reilly, H. L. (1941). $\frac{\bar{\sigma}}{\bar{T}}$

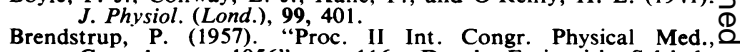
Copenhagen 1956", p. 116. Dansk Fysiurgisk Selskab,

Glogowski, G., and Wallraff, J. (1951). Ztschr. Ortopädie, 80, 237.

Lange, F. (1925). Münch. med. Wschr., 72, 1626.

Ropes, M. W., Robertson, W. B., Rossmeisl, E. C., Peabody, R. B., and Bauer, W. (1947). Acta med scand., Suppl. 196, p. 700. Schade, H. (1921). Münch. med. Wschr., 68, 95.
Stockman, R. (1920). "Rheumatism and Arthritis". Green, $\frac{\omega}{\text { Dิ }}$ Wegelius, O., and Asboe-Hansen, G. (1956). Exp. Cell Res., 11, 437 응

Altérations morphologiques et chimiques du tissu conjonctif dans les muscles atteints de fibrosite

RÉSUMÉ

Des analyses histologiques et chimiques faites sur des $\bigcirc$ biopsies de muscles atteints de fibrosite ont permis de constater une augmentation de mucopolysaccharides $\square$ acides, une teneur augmentée en eau, localisée à l'espace $\mathbb{D}$ extracellulaire, et une augmentation du taux de chlorure et d'hexosamine.

Une légère accumulation de “Mastzellen" a été observée dans des tranches histologiques.

Alteraciones morphologicas y quimicás del tejido co co nectivo en los muscúlos fibrosíticos

RESUMEN

Investigaciones histoquímicas y químicas de biopsias de músculos fibrositicos manifestaron un aumento de $\bar{\partial}$ mucopolisacáridos ácidos y del contenido de agua, ٌحٌ localizado al espacio extracelular, y un aumento de $\mathbb{D}$ cloruro y de hexosamina.

Se observó una leve aglomeración de "Mastzellen" $\overline{\text { Oี }}$ en cortes histológicos. 